\title{
Decision Support System Analysis Performance Evaluation Lecturer Using Balanced Scorecard Method In a private University
}

\author{
Adi Rachmanto \\ Universitas Komputer Indonesia \\ Bandung, Indonesia \\ adirachmanto@email.unikom.ac.id
}

\begin{abstract}
The purpose of this study was to develop a decision support system. In analyzing system requirements, this study uses a balanced scorecard method based on 4 perspectives, namely: customer perspective, financial perspective, internal process perspective and growth perspective. The results of this study are to: 1) determine strategic objectives from each perspective based on the vision, mission and strategy of A private University. 2) Determine the size and weight of assessment of performance indicators in the form of Key Performance Indicators (KPI) and 3) Analyze data requirements from the parts involved by integrating existing systems, so that they can be used for analysis of the performance assessment decision support system lecturer. The impact with the development of this decision support system include: 1) Lecturers will get the results of the overall performance evaluation of the lecturer. 2) can increase the motivation of lecturers due to the clear indicators used in determining reward / intensive that will be given.
\end{abstract}

Keywords- Decision Support System, Performance Evaluation Lecturer, and Balanced Scorecard.

\section{INTRODUCTION}

The performance appraisal in an institution greatly influences the quality and sustainability of the institution, this is because the performance assessment can encourage employees at the institution to be more active in improving the quality of their work. A private University is an institution engaged in education which has been established since 2000, continues to strive to be able to develop its institution from Good University towards Great University. The process of monitoring and assessing the performance of lecturers at A private University is carried out in stages, starting monthly monitoring by the Study Program Quality Assurance (QA) section through an online guardianship site in the syllabus check feature, which monitors the suitability of the lecture material delivered with the Syllabus as determined by the Study Program.

Several studies related to the development of decisionmaking information systems, among others: Yasrin Zabidi discussed the Design of a Performance Assessment System at STT Adisutjipto as a supporter of the quality assurance system [1]. Hamzah, Suyoto, Paulus Mudjihartono explained the decision support system for assessing lecturer performance with the balanced scorecard case study method at the university respati Yogyakarta [2]. Suryaman and Hamdan (2016) discussed the performance measurement of UNSERA lecturers with the balanced scorecard approach [3]. From some of the results of the study, it has been successful in designing a decisionmaking system for lecturer performance using the balanced scorecard method.

Based on the explanation above, the purpose of this study is to develop a decision support system for lecturer performance assessment. In analyzing system requirements, this study uses a balanced scorecard method based on 4 perspectives, namely: customer perspective, financial perspective, internal process perspective and growth perspective.

\section{METHOD}

The research phase describes the steps that will be taken during the research. In general, the stages of the research that will be carried out in the analysis of the support system for the decision of lecturer performance appraisal at University $\mathrm{X}$ can be seen in Figure 1 as follows: 


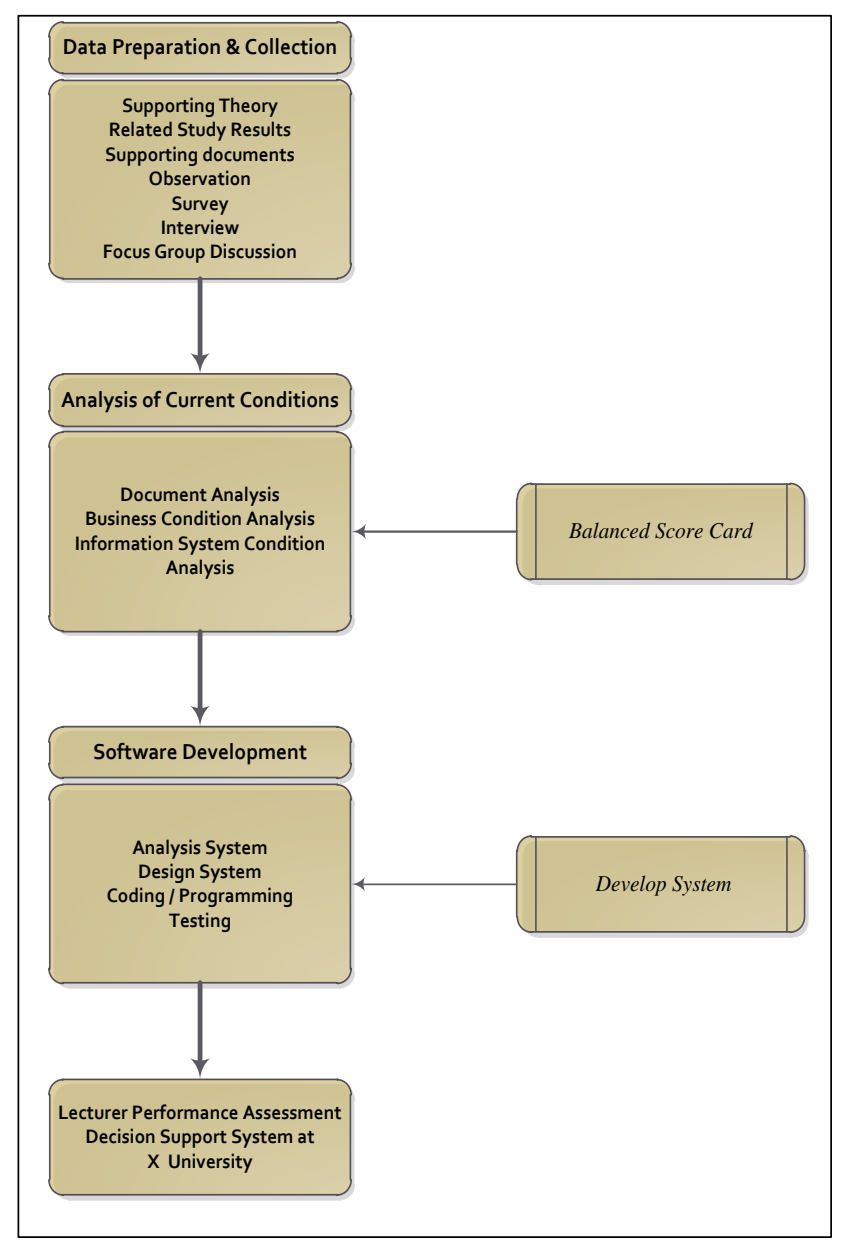

Fig 1. Stages of Research

\section{RESULTS AND DISCUSSION}

A. Statement of A private University Vision, Mission and Strategic Objectives

The statement of the vision, mission and goals of the A private University in the 2016-2020 Strategic Plan [4], can be seen in table 1 below:

TABLE I. STATEMENT OF VISION, MisSION \& OBJECTIVES OF A PRIVATE UNIVERSITY

\begin{tabular}{|l|}
\hline VISION \\
\hline To be a leading university in the field of Information \& \\
Communication Technology, Global insightful, spirited \\
entrepreneur and to be a leading Centre in the field of \\
Science and Technology that supports the National \\
Development and oriented to the interests of the \\
Community, Nation and State. \\
\hline MISSION \\
\hline
\end{tabular}

Providing a modern higher education based on the culture of the organization of UNIKOM, PIQIE (Professionalism, Integrity, Quality, Information Technology, Excellence), with a conducive Educational System and Study Programs that are based on software, Hardware, Entrepreneurship and Multimedia Animation, by optimizing existing resources based on the Principles of Efficiency, Effectiveness and Productivity.

\section{GOAL}

To create excellent graduates in the field of information and communication technology, competent and reliable in their field of study, have the spirit of entrepreneurship, polite and virtuous, have commitment to advancing the nation and the state and faithful and devoted to Almighty God.

\section{B. Strategic Objetive Formulation using the Balanced Scorecard method}

The Balanced Scorecard method was introduced by Kaplan and Norton [5], providing a comprehensive framework for describing the vision into strategic objectives. The goals of a comprehensive strategy can be formulated because of the balanced scorecard method, using four perspectives: financial, customer, internal business processes, learning and growth.

Based on the Development Strategy Plan for 2016-2020 A private University which has a direct relation to the lecturers' performance, it can be formulated as a A private University strategy goal which we then classify according to the balance scorecard perspective, can be seen from table 2 as follows:

TABLE II. CLASSIFICATION OF STRATEGIC TARGETS BASED BALANCE SCORECARD PERSPECTIVE

\begin{tabular}{|c|c|c|}
\hline No & Perspective & Strategic Goals \\
\hline 1 & Financial & $\begin{array}{l}\text { a) Providing or seeking } \\
\text { various research funding } \\
\text { sources such as national } \\
\text { and international } \\
\text { research grants. } \\
\text { b) Looking for various } \\
\text { sources of community } \\
\text { service funds }\end{array}$ \\
\hline 2 & Customer & $\begin{array}{l}\text { Improving Student Process } \\
\text { Quality \& Output }\end{array}$ \\
\hline 3 & $\begin{array}{l}\text { Internal } \\
\text { Business } \\
\text { Process }\end{array}$ & $\begin{array}{l}\text { a) Increase the value \& } \\
\text { status of Departement \& } \\
\text { Institutional } \\
\text { Accreditation } \\
\text { b) Increase Achievement } \\
\text { of National \& } \\
\text { International } \\
\text { Achievements } \\
\text { c) Improve the ranking of } \\
\text { UNIKOM according to }\end{array}$ \\
\hline
\end{tabular}




\begin{tabular}{|c|c|c|}
\hline No & Perspective & Strategic Goals \\
\hline & & $\begin{array}{l}\text { Kemristekdikti, } \\
\text { Webometrics \& 4ICU } \\
\text { d) Evaluate \& improve the } \\
\text { quality of the HR } \\
\text { management system } \\
\text { e) Building an integrated } \\
\text { infrastructure and } \\
\text { information system } \\
\text { f) Building a complete, } \\
\text { effective and objective } \\
\text { decision-making } \\
\text { support system }\end{array}$ \\
\hline 4 & $\begin{array}{l}\text { Learning \& } \\
\text { Growth }\end{array}$ & $\begin{array}{l}\text { a) Evaluate \& improve the } \\
\text { quality of the HR } \\
\text { management system } \\
\text { b) Providing opportunities } \\
\text { for advanced S3 study } \\
\text { lecturers \& participating } \\
\text { in improving } \\
\text { competence } \\
\text { c) Increase the amount \& } \\
\text { quality of research. } \\
\text { d) Increase the number \& } \\
\text { quality of community } \\
\text { service. }\end{array}$ \\
\hline
\end{tabular}

\section{Lecturer Performance Indicators}

Performance can be seen from a person's ability to achieve goals, including perseverance to work hard, timeliness of completing work, use of costs according to design, independence of work in the sense of not always needing supervision, and the ability to overcome problems or obstacles. Ivancevich, John M, Konopaske Robert \& Matteson Michael T [6].

Based on the strategic objectives that have been formulated, the researcher then formulates lecturer performance indicators and formulas from each point which can be seen in table 3 as follows:

TABLE III. LeCtURER PERFORMANCE IndiCATORS

\begin{tabular}{|l|l|}
\hline \multicolumn{1}{|c|}{ Strategic Goals } & $\begin{array}{c}\text { Key Performance Indikator } \\
\text { (KPI) }\end{array}$ \\
\hline $\begin{array}{l}\text { 1). Financial } \\
\text { a) Providing or seeking } \\
\text { various research funding } \\
\text { sources such as national } \\
\text { and international research } \\
\text { grants. }\end{array}$ & $\begin{array}{l}\text { 1. Research Grants } \\
\text { 2. Publication Grants } \\
\text { Grants }\end{array}$ \\
$\begin{array}{l}\text { Looking for various } \\
\text { sources of community } \\
\text { service funds }\end{array}$ & $\begin{array}{l}\text { 1. The number of guardian } \\
\text { students who have been } \\
\text { approved by their } \\
\text { guardianship. }\end{array}$ \\
\hline $\begin{array}{l}\text { Consumer } \\
\text { Improving Student Process } \\
\text { Quality \& Output }\end{array}$ & $\begin{array}{l}\text { 2. Upload the syllabus \& } \\
\text { instructional materials at } \\
\text { the Online Lecture Site }\end{array}$ \\
& $\begin{array}{l}\text { 3. Charging Syllabus \& } \\
\text { Online Attendance }\end{array}$ \\
\hline
\end{tabular}

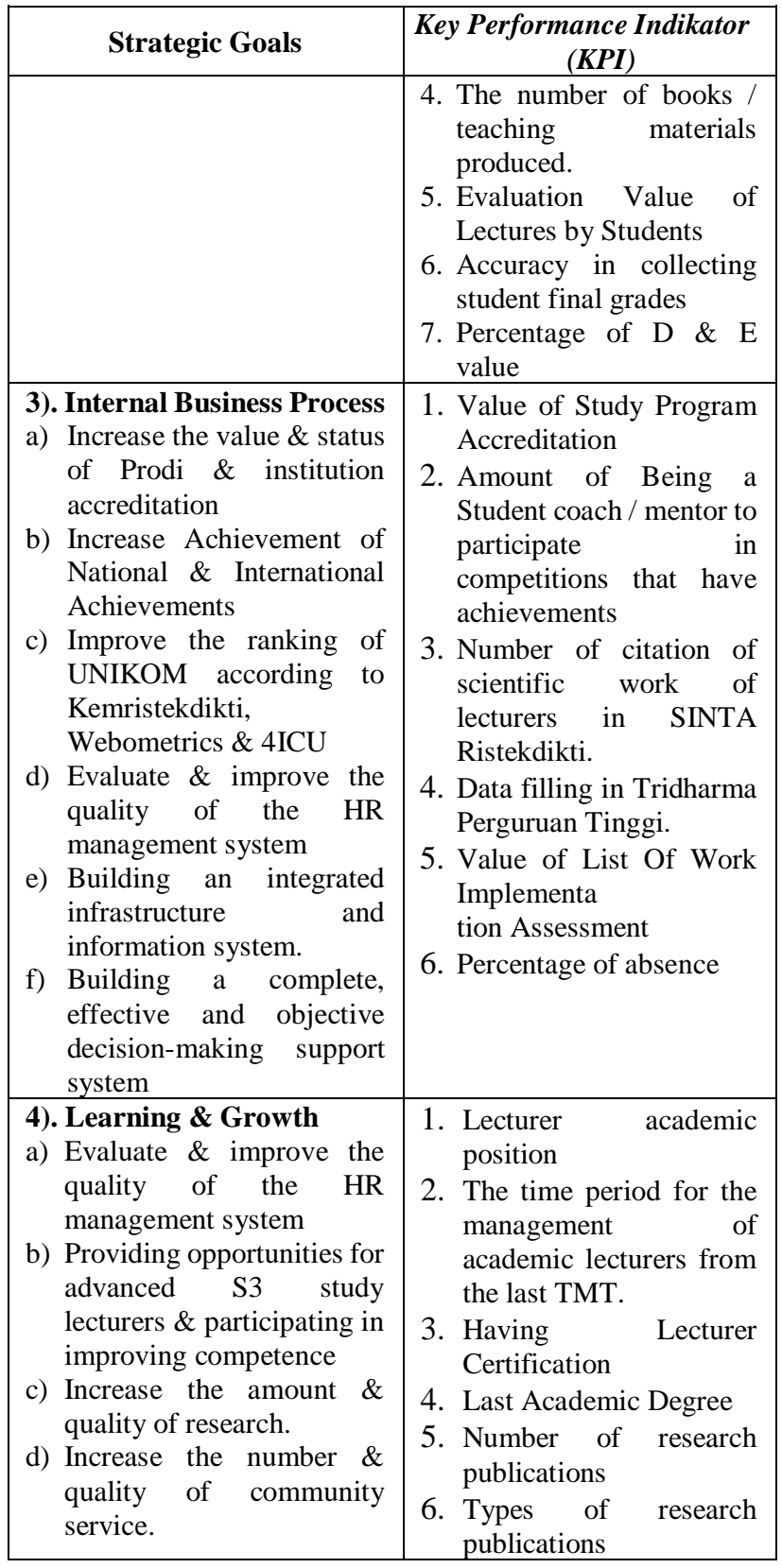

\section{Lecturer Performance Assessment}

Based on the literature documents / guidelines for Institutional lecturer evaluation obtained data in the form of lecturer performance assessment weights as in table 4 .

\begin{tabular}{|c|c|c|}
\hline \multirow{2}{*}{ No } & Criteria & \multirow{2}{*}{$\begin{array}{c}\text { Bobot } \\
(\%)\end{array}$} \\
\hline & Teaching and Learning Process & \\
\hline \multirow{5}{*}{1} & $\begin{array}{l}\text { 1. Upload the syllabus \& instructional } \\
\text { materials at the Online Lecture Site }\end{array}$ & 3 \\
\hline & 2. Charging Syllabus \& Online Attendance & 4 \\
\hline & 3. Accuracy in collecting student final grades & 5 \\
\hline & 4. Percentage of D \& E values & 3 \\
\hline & 5. Evaluation Value of Lectures by Students & 5 \\
\hline
\end{tabular}




\begin{tabular}{|c|c|c|}
\hline & 6. The book / teaching material produced. & 5 \\
\hline & Guidance \& Consultation & \\
\hline & $\begin{array}{l}\text { 1. The number of guardian students who } \\
\text { have been approved by their guardianship. }\end{array}$ & 3 \\
\hline 2 & $\begin{array}{l}\text { 2. Providing guidance on Internship / Job } \\
\text { Training \& Thesis }\end{array}$ & 3 \\
\hline & $\begin{array}{l}\text { 3. Amount of Being a Student coach / mentor } \\
\text { to participate in competitions that have } \\
\text { achievements. }\end{array}$ & 4 \\
\hline & Career Level \& Lecturer Absence & \\
\hline & 1. Lecturer academic position & 5 \\
\hline & $\begin{array}{l}\text { 2. The period of time for the management of } \\
\text { academic lecturers from the last TMT. }\end{array}$ & 5 \\
\hline 3 & 3. Having Lecturer Certification & 5 \\
\hline & 4. Last Academic Degree & 5 \\
\hline & 5. DP3 value & 2 \\
\hline & 6. Percentage of absence & 3 \\
\hline & Research & \\
\hline & 1. Types of research publications & 10 \\
\hline 4 & 2. Types of Research Grants & 5 \\
\hline & 3. Obtain Publication Grants & 2 \\
\hline & $\begin{array}{l}\text { 4. Number of citation of scientific work of } \\
\text { lecturers in SINTA Ristekdikti. }\end{array}$ & 3 \\
\hline & Community service & \\
\hline 5 & 1. Conduct Community Service & 7 \\
\hline & 2. Types of Community Service Grants & 3 \\
\hline & Other Tasks & \\
\hline & 1. Serving as an activity committee & 2 \\
\hline 6 & 2. Participating in Seminars \& Training & 3 \\
\hline & $\begin{array}{l}\text { 3. Completion of Tridharma Perguruan } \\
\text { Tinggi data. (HR / SISTER) }\end{array}$ & 3 \\
\hline & 4. Study Program Accreditation Value & 2 \\
\hline
\end{tabular}

\section{E. Decision Support Systems}

A decision support system according to Whitten, Bentley \& Dittman [7] is an information system that helps identify decision-making opportunities or provides information to assist decision making. Meanwhile, according to Turban, Efraim, et al. [8] Decision support system is an information system that is used to help midlevel managers in semi-structured decision making processes be more effective by using analytical models and available data.

\section{F. Analysis of Information System Conditions}

The condition of the information system that is already running is illustrated through the Context Diagram in Figure 2. It can be seen that external entities: Universities, Faculties, Study Programs provide information about the strategic objectives of the institution related to the performance of lecturers. Other external entities: Students, Lecturers, ICT, LPPM enter the data needed in the Balanced Scorecard analysis according to each unit which will later be used to make lecturer performance appraisals that will be written in the form of reports.

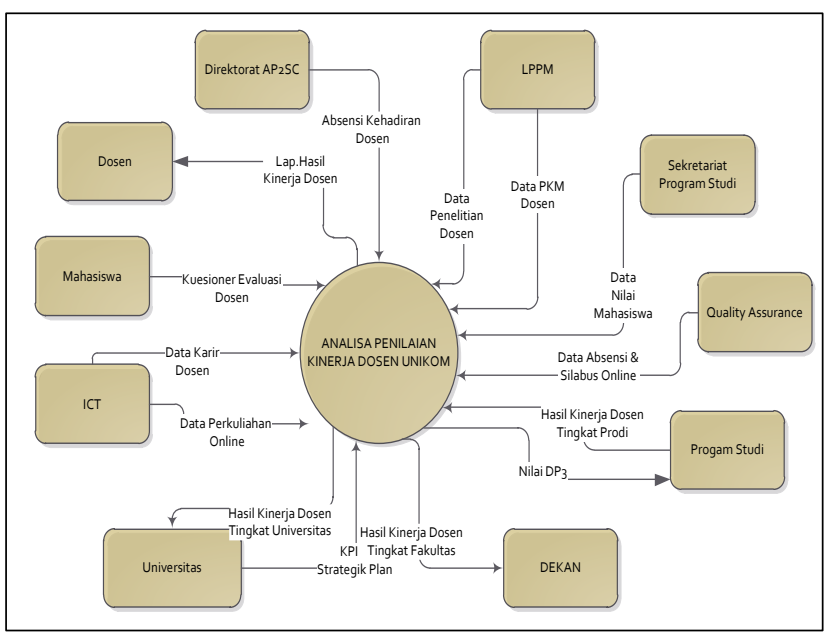

Fig 2. Context Diagram Analysis of Information System Conditions

To carry out the process of evaluating the performance of lecturers, it cannot be separated from the role of the supporting unit of the institution in providing data and information related to the track record of the lecturer in implementing the tri dharma of higher education in a certain period of time. In the Context Diagram there are several external entities involved in the process of assessing lecturer performance as a source of data and information in the Balanced Scorecard analysis.

The research that has been produced by Hamzah, Suyoto, Paulus Mudjihartono [1] discusses the support system for the decision on the assessment of lecturers' performance using the balanced scorecard case study method at respati Yogyakarta University. The results of the study can formulate the performance indicators of lecturers and their weight, as well as in the development of integrated lecturer performance assessment software based on the data sources of each supporting unit in an existing institution. Referring to the previous research, the deeper development of the context diagram that has been drawn above, can be formed subsystems from the external entity process to the Balanced Scorecard analysis process as in table 4 .

TABLE V. DATA SOURCES AND SUBSYSTEMS

\begin{tabular}{|lr|c|c|}
\hline \multicolumn{2}{|c|}{$\begin{array}{c}\text { Strategic Goals } \\
\text { (SG) \& KPI }\end{array}$} & Data source & Sub System \\
\hline $\begin{array}{l}\text { SG : 1). Financial } \\
\text { KPI : }\end{array}$ & $\begin{array}{c}\text { Research } \\
\text { institutions and }\end{array}$ & $\begin{array}{c}\text { simlitabmas } \\
\text { Unikom }\end{array}$ \\
$\begin{array}{l}\text { 1. Obtain grant } \\
\text { funding for } \\
\text { research. }\end{array}$ & $\begin{array}{c}\text { community service } \\
(\text { LPPM })\end{array}$ & \\
\hline
\end{tabular}




\begin{tabular}{|c|c|c|}
\hline $\begin{array}{l}\text { Strategic Goals } \\
\text { (SG) \& KPI }\end{array}$ & Data source & Sub System \\
\hline $\begin{array}{l}\text { 2. Obtain grants for } \\
\text { publication of } \\
\text { research results. } \\
\text { 3. Obtain funding } \\
\text { for community } \\
\text { service grants }\end{array}$ & & \\
\hline $\begin{array}{l}\text { SG : 2). Consumer } \\
\text { KPI : } \\
\text { 1. Lecturers } \\
\text { conduct online } \\
\text { guardianship at } \\
\text { the appointed } \\
\text { time } \\
\text { 2. The lecturer } \\
\text { informs the } \\
\text { syllabus and } \\
\text { teaching } \\
\text { materials before } \\
\text { the lecture at the } \\
\text { online lecture } \\
\text { site. } \\
\text { 3. Active lecturers } \\
\text { in writing books / } \\
\text { teaching } \\
\text { materials. } \\
\text { 4. Lecturers input } \\
\text { student } \\
\text { attendance lists } \\
\text { online. } \\
\text { 5. Student } \\
\text { satisfaction in } \\
\text { the learning } \\
\text { process. } \\
\text { 6. Gather the final } \\
\text { score according } \\
\text { to the one } \\
\text { specified. } \\
\text { 7. The level of } \\
\text { graduation of } \\
\text { students in } \\
\text { higher education. }\end{array}$ & $\begin{array}{ll}\text { 1. } & \text { ICT \& } \\
\text { Multimedia } \\
\text { 2. Quality } \\
\text { Assurance } \\
\text { 3. Department } \\
\text { Secretariat }\end{array}$ & $\begin{array}{l}\text { 1. Online Lecture } \\
\text { 2. Online } \\
\text { Trusteeship } \\
\text { 3. Chechking } \\
\text { System } \\
\text { Syllabus } \\
\text { 4. Online } \\
\text { Attendance } \\
\text { Sub System } \\
\text { 5. Staffing } \\
\text { System } \\
\text { 6. Academic } \\
\text { Information } \\
\text { System }\end{array}$ \\
\hline $\begin{array}{l}\text { SG : 3). Internal } \\
\text { Business Process } \\
\text { KPI : } \\
\text { 1. Lecturers } \\
\text { participate in the } \\
\text { accreditation } \\
\text { process } \\
\text { 2. Involvement of } \\
\text { lecturers as } \\
\text { mentors \& } \\
\text { coaches } \\
\text { students } \\
\text { competition } \\
\text { activities. } \\
\text { 3. Lecturers instruct } \\
\text { students to access } \\
\text { lecturers' } \\
\text { scientific work to } \\
\text { be used as } \\
\text { sources in student } \\
\text { research. } \\
\text { 4. Lecturers carry } \\
\text { out the process } \\
\text { professionally } \\
\text { and responsibly }\end{array}$ & $\begin{aligned} \text { 1. } & \text { ICT \& } \\
\text { 2. } & \text { Multimedia } \\
& \text { AP2SC } \\
& \text { Directorate }\end{aligned}$ & $\begin{array}{l}\text { 1. Eis Unikom } \\
\text { 2. Online } \\
\text { Lecture } \\
\text { 3. Staffing } \\
\text { System } \\
\text { 4. SmartApps }\end{array}$ \\
\hline
\end{tabular}

\begin{tabular}{|c|c|c|}
\hline $\begin{array}{l}\text { Strategic Goals } \\
\text { (SG) \& KPI }\end{array}$ & Data source & Sub System \\
\hline $\begin{array}{l}\text { 5. The presence of } \\
\text { lecturers in } \\
\text { accordance with } \\
\text { the applicable } \\
\text { provisions. } \\
\text { 6. Periodically, } \\
\text { lecturers update } \\
\text { their activity data } \\
\text { in HR Online. }\end{array}$ & & \\
\hline $\begin{array}{l}\text { SG : 4). Learning } \\
\text { \& Growth } \\
\text { KPI : } \\
\text { 1. Lecturers } \\
\text { continuously take } \\
\text { care of their } \\
\text { academic } \\
\text { positions. } \\
\text { 2. Lecturers have } \\
\text { been } \\
\text { acknowledged to } \\
\text { their } \\
\text { professionals by } \\
\text { the state } \\
\text { 3. The last lecturer } \\
\text { academic degree } \\
\text { 4. Scientific } \\
\text { publications } \\
\text { carried out every } \\
\text { semester. }\end{array}$ & $\begin{array}{ll}\text { 1. } & \text { Public } \\
\text { Administration } \\
\text { Bureau } \\
\text { 2. } & \text { ICT \& } \\
\text { Multimedia } \\
\text { 3. } & \text { LPPM }\end{array}$ & $\begin{array}{ll}\text { 1. } & \text { Staffing } \\
& \text { System } \\
\text { 2. } & \text { UNIKOM } \\
& \text { Simlitabmas }\end{array}$ \\
\hline
\end{tabular}

\section{CONCLUSION}

Based on the results of the study it can be concluded that: 1. Assessment of lecturer performance with the balanced scorecard method has 3 objective perspectives on financial strategies, namely Lecturer Honorarium, External Grants / Funds, Stimulant Funds; 2 strategic perspectives of customer goals, namely increasing student satisfaction, increasing lecturer satisfaction; 4 strategic objectives of internal business process perspectives, namely Percentage of Attendance Attendance, Availability Percentage of Questions, Percentage of Gathering Value, Guidance; and 4 growth strategic objectives and perspective learning, namely the percentage of lecturer research, percentage of community services, percentage of scientific publication, percentage of lecturer education. In developing integrated lecturer performance evaluation software based on data sources from each supporting unit in the institution there are several subsystems that already exist at University X.

\section{REFERENCES}

[1] Yasrin Zabidi, 2007, Perancangan Sistem Penilaian Kinerja di STT Adisutjipto sebagai pendukung sistem penjamin mutu, Jurnal Ilmiah Teknik Industri Vol. 5 No. 3

[2] Hamzah, Suyoto, Paulus Mudjihartono, 2010, Sistem Pendukung Keputusan Penilaian Kinerja Dosen Dengan Metode Balanced Scorecard (Studi Kasus: Universitas Respati Yogyakarta), Seminar Nasional Informatika 2010, ISSN: 1979-2328, Yogyakarta. 
[3] Suryaman dan Hamdan, 2016, Pengukuran Kinerja Dosen Unsera Dengan Pendekatan Balanced Scorecard, CENDEKIA, Vol. 10, No. 2.

[4] Rencana Strategis (Renstra) UNIKOM 2016-2020

[5] Kaplan. R. S. dan David P. Norton, 2000, Balanced scorecard, Menerapkan Strategi Menjadi Aksi, Erlangga, Jakarta.

[6] Ivancevich, John M, Konopaske Robert \& Matteson Michael T, 2007, Perilaku Dan Manajemen Organisasi (Alih Bahasa Gina Gania), Edisi Tujuh, Erlangga, Jakarta.

Indrajit, Eko,R; Djokopranoto, 2006, Manajemen Perguruan Tinggi Modern. Penerbit Andi , Yogyakarta.

[7] Jeffrey L.Whitten, Lonnie D. Bentley, Kevin C. Dittman, 2009, Metode Desain dan Analisis Sistem, Edisi I, Cetakan 10, Penerbit Andi, Yogyakarta

[8]Turban, Efraim, et al. 2005. Decision Support Systems and Intelligent System, 7th Ed. New Jersey : Pearson Education. 